\title{
Between Ecclesiology and Diplomacy: Francisco de Vargas and the Council of Trent
}

XAVIER TUBAU

Hamilton College

This article examines the letters and reports of Francisco de Vargas (ca. 1500-66), a jurist who served in different positions under Charles V and Philip II during the three phases of the Council of Trent. Vargas defended the superiority of the council over the pope in matters of faith and practices and drew attention to the need to continue the reform of the Roman Curia started at the Council of Constance. The article examines the way this conciliarist adapted ecclesiology to developing circumstances over the three phases of the Council of Trent, and points out the need to revise the monolithic, papalist view that historiography continues to present of early modern Spanish ecclesiological thought.

Cet article examine les lettres et les rapports de Francisco de Vargas (ca. 1500-66), un juriste qui a occupé diverses positions sous Charles V et Philippe II durant les trois phases du Concile de Trente. Vargas a défendu la supériorité du concile sur le pape dans les matières de foi et les pratiques religieuses, tout en attirant l'attention sur la nécessité de poursuivre la réforme de la Curie romaine débutée lors du Concile de Constance. Cet article examine la manière dont ce conciliariste a adapté l'ecclésiologie à de nouvelles circonstances pendant les trois phases du Concile de Trente, et souligne la nécessité de réviser la représentation monolithique et papiste que l'historiographie continue à présenter de la pensée ecclésiologique renaissante espagnole.

The role of the Spanish legation at the Council of Trent is due for a reassessment. According to the account articulated by Catholic historiography at the end of the nineteenth century, Spanish prelates shaped Tridentine reform and reinforced the authority of the pope in the Catholic world against the Protestant Reformation. Marcelino Menéndez Pelayo pointed out that the Spanish prelates never challenged "the authority of the pope, nor sought to renew the disastrous cases of Constance and Basel."1 Decades later, Hubert Jedin was still claiming that the actions of the Spaniards at Trent were not carried out "in the spirit of extreme conciliarism but in the sense of a moderate episcopalism." ${ }^{2}$ More recent research has demonstrated that this interpretation simplifies a much more complicated spectrum of ecclesiological

1. Marcelino Menéndez Pelayo, Historia de los heterodoxos españoles, 2 vols. (Madrid: Librería Católica de San José, 1880), 2:685. All translations in this article are mine, unless otherwise stated.

2. Hubert Jedin, Papal Legate at the Council of Trent: Cardinal Seripando (London: Herder, 1947), 582.

Renaissance and Reformation / Renaissance et Réforme 42.3, Summer / été 2019 
ideas. ${ }^{3}$ In order to advance our knowledge of this topic, my intention in this article is to present an analysis of the ecclesiological ideas and diplomatic activity of Francisco de Vargas y Mejía (ca 1500-66), a Spanish jurist who played a major role in Italy as a political agent of Charles V and Philip II. Vargas is a well-known figure to scholars of Spanish diplomacy on Italian territory and the history of the Council of Trent. He worked as an adviser to the imperial ambassador, Francisco de Toledo, during the first two periods of the Council of Trent from 1545 to 1548, and from 1551 to 1552. After some years of service as ambassador in the Republic of Venice between 1552 and 1558, he held office as Philip II's ambassador in the Holy See between 1559 and 1563, in other words, during the negotiations to resume the council and its subsequent development until it came to an end in December 1563. Despite the importance of his role as adviser and ambassador to Charles V and Philip II at a critical juncture in the religious and political history of the sixteenth century, Vargas has still not received the monographic study that his position deserves. ${ }^{4}$ This article is a first step in that direction.

The information that we have of the life and work of Vargas comes basically from his years as an adviser and ambassador in Italy (1545-63). ${ }^{5}$ have been unable to ascertain the university where he studied law, or whether

3. Ignasi Fernández Terricabras, Felipe II y el clero secular. La aplicación del Concilio de Trento (Madrid: Sociedad Estatal para la Conmemoración de los Centenarios de Felipe II y Carlos V, 2000), 69-95; Lu Ann Homza, Religious Authority in the Spanish Renaissance (Baltimore: Johns Hopkins University Press, 2000), 113-48; Ulrich Horst, Die Lehrautorität des Papstes und die Dominikanertheologen der Schule von Salamanca (Berlin: Akademie Verlag GmbH, 2003), 61-74.

4. The only recent study of Vargas is the one by Miles Pattenden, "From Ambassador to Cardinal? Francisco de Vargas at the Papal Court (1559-63)," in Embajadores culturales. Transferencias y lealtades de la diplomacia española de la edad moderna, ed. Diana Carrió-Invernizzi (Madrid: Editorial UNED, 2016), 139-56, in which he assesses Vargas's diplomatic activity as ambassador to Rome during the papacy of Pius IV.

5. For the life of Vargas, see Nicolás Antonio, Bibliotheca Hispana Nova, 2 vols. (Madrid: Ibarra, 1783), 1:493-94; Constancio Gutiérrez, Españoles en Trento (Valladolid: Consejo Superior de Investigaciones Científicas-Instituto Jerónimo Zurita, 1951), 478-93 (in this book, Gutiérrez edited and annotated a bibliographical catalogue of those who attended the council, drawn up between 1727 and 1738 and kept in the Colegio Mayor de Santa Cruz de Valladolid); Gustave Constant, Rapport sur une mission scientifique aux archives d'Autriche et d'Espagne, in Nouvelles archives des missions scientifiques et littéraires 18.5 (1910): 175-537, 359-85. 
he completed a doctorate. ${ }^{6}$ The first documented item of information that we have about his life is that he was appointed attorney-general ("Fiscal") of the Council of Castile on 1 May 1543. ${ }^{7}$ The president of the council in May 1543 was Fernando de Valdés, the future inquisitor-general and archbishop of Seville. ${ }^{8}$ As attorney-general of the council, Vargas's function was to safeguard the rights of the royal patronage in Castile, specifically the conflicts deriving from the exercise of royal and ecclesiastical jurisdiction. ${ }^{9}$ This responsibility explains why Charles V opted to send him to the Council of Trent as the representative of the Kingdom of Castile, together with Martín de Soria Velasco, auditor of the Chancery of Valladolid. A third jurist, Joan Quintana, was also appointed to represent the Kingdom of Aragon. ${ }^{10}$ In the words of the papal legates at Trent in July 1545, five months before the council started, these "three doctors from Spain $[\ldots]$ are coming well equipped to defend their pragmatics" and to protest about "the infinite abuses" of Rome. ${ }^{11}$

Vargas, Velasco, and Quintana played modest roles at the council until the moment when Francisco de Toledo, who had been appointed imperial ambassador to the council in March 1546, left the city in December of the same

6. Antonio, 1:493, pointed out that Vargas studied in the Colegio Mayor San Ildefonso de Alcalá, although I have not been able to confirm this detail.

7. Pedro Gan Giménez, El Consejo Real de Carlos V (Granada: Universidad de Granada, 1988), 137 and 270. He would keep his post and pay until 22 May 1552, despite the fact that he was at Trent from June 1545.

8. José Luis G. Novalín, El inquisidor general Fernando de Valdés (1483-1568) (Oviedo: Universidad de Oviedo, 1968), 109-62. It is recorded that when Vargas was ambassador in Rome he defended the interests of Valdés in the proceedings opened against him in Rome to disqualify him as a judge in Carranza's trial on the grounds of prejudice (357-60).

9. Ignacio Ezquerra Revilla, El Consejo Real de Castilla bajo Felipe II. Grupos de poder y luchas faccionales (Madrid: Sociedad Estatal para la Conmemoración de los Centenarios de Felipe II y Carlos V, 2000), 36. 10. See Corpus Documental de Carlos V, ed. Manuel Fernández Álvarez, 5 vols. (Salamanca: Universidad de Salamanca, 1973-79): 2:341; and El Concilio de Trento. Documentos procedentes del Archivo General de Simancas, ed. Manuel Ferrandis, 2 vols. (Valladolid: Imprenta Casa Social Católica, 1928), 1:37. The announcement of the three appointments was already in Rome on March 14 (Concilium Tridentinum: Diariorum Actorum Epistularum Tractatuum nova collectio, 13 vols. (Friburg: Herder, 1901-2001), 10:15; hereafter, CT.

11. "Sono comparsi tre dottori di Spagna [...] s'intende, che vengono bene armati per defendere le loro pragmatiche, et in oltra per fare altre querele d'infiniti abusi" (CT, 10:147). 
year to deal with various matters in Florence. ${ }^{12}$ Charles $\mathrm{V}$ determined that the three would act as "solicitors" during Toledo's absence and always under the supervision of Pedro Pacheco, Cardinal of Jaen. ${ }^{13}$ Shortly after the departure of Toledo, Pacheco wrote a letter rebuking the three jurists for not having informed Toledo about what was happening at the council and for not having supported the interests of the emperor in negotiations about the decree on justification, all of which would earn them a sharp reprimand from Charles V. ${ }^{14}$ Perceptions of the way Vargas and Velasco in particular acted soon improved, however, and they would both play significant roles as a result of the council's move from Trent to Bologna, since they were the ones who made the formal protest on behalf of Charles $\mathrm{V}$ in that city. ${ }^{15}$

Vargas remained in Trent after the death of Pope Paul III in 1549 and became the only adviser to the ambassador, Fernando de Toledo, during the second phase of the council (1551-52). His regular correspondence with Antoine Perrenot de Granvelle shows that Vargas had become a key agent on the imperial side at the council. ${ }^{16}$ Vargas would send him copies of the drafts examined by the congregations (which was expressly forbidden), and lay out in detail his thoughts and opinions of how the negotiations with the legates ought to proceed. Nor was he afraid to express opinions different from those of the ambassador himself, such as whether the council should continue or be suspended. ${ }^{17}$ Granvelle gave Vargas his unconditional support in the following years. On 5 April 1552, probably as a reward for his management of the second period of the council, Vargas was appointed imperial ambassador to the Republic of Venice; Charles V wrote to him, expressing his confidence

12. $C T, 10: 752$.

13. CT, 11:80.

14. CT, 11:97 (Pacheco), 101 (Charles V). See Ángel Martín González, El cardenal don Pedro Pacheco, Obispo de Jaén, en el Concilio de Trento, 2 vols. (Madrid-Jaén: Consejo Superior de Investigaciones Científicas-Instituto de Estudios Giennenses, 1974), 2:18-20.

15. CT, 11:265, 289, 296, 300. For the death threat that Vargas received from Bishop Jacomellis to dissuade him from moving to Bologna, see CT, 11:346.

16. See all the correspondence edited by Constancio Gutiérrez in the first two volumes of Trento: un concilio para la unión, 3 vols. (Madrid: Consejo Superior de Investigaciones Científicas, 1981). For the history of this correspondence, see note 38 .

17. Gutiérrez, Trento: un concilio, 1:672-80. 
that he would carry out the office "with the prudence, skill and adroitness that experience has shown." ${ }^{18}$

During his years in Venice, it is recorded that Vargas was one of the patrons of Titian and that the painter made a portrait of him. This portrait is now lost but is described in poems by Juan Páez de Castro and Pietro Aretino. ${ }^{19}$ Vargas was also one of the jurists consulted by Philip II-together with Melchor Cano and Domingo de Soto, among others-concerning the best way to handle the provocations of Pope Paul IV in $1556 .{ }^{20}$ The end of his period in office as ambassador in Venice was marked by the beginning of the conflict over precedence at the beginning of 1557. The abdication of Charles $\mathrm{V}$ and the division of his patrimony between Ferdinand I and Philip II led to the French ambassador in Venice, Dominique du Gabre, demanding to be accorded precedence in diplomatic honours over the Spanish ambassador, given that Vargas could no longer be considered the imperial ambassador. Vargas tried unsuccessfully to retain precedence during a long campaign lasting months. In the end, the situation simply became untenable and Philip II, on the advice of Vargas himself, decided to withdraw his envoy from Venice. ${ }^{21}$

Vargas spent the fall and winter of 1558 in Rome, where he dealt with the formalities associated with supporting the reorganization of the Catholic church in the Low Countries being undertaken by Granvelle. ${ }^{22}$ In February 1559, he travelled to the city of Ghent in Flanders, where the court of Philip II was. The king had just left England after the death of Mary I (17 November 1558) and was dealing with the preparations for peace with France in the Treaty

18. "con la prudencia, dexteridad y buena manera que la experiencia lo ha mostrado" (Gutiérrez, Trento: un concilio, 2:371).

19. Juan Páez de Castro, Poesía latina, ed. and trans. Eduardo del Pino González and Ignacio J. García Pinilla (Cuenca: Ediciones de la Universidad de Castilla-La Mancha, 2017), 168-71; Pietro Aretino, Il sesto libro delle lettere (Paris: Matteo il Maestro, 1609), 193-94.

20. Antonio Cánovas del Castillo in his article "Roma y España a mediados del siglo XVI," Revista de España 2 (1868): 5-48, 23-25. For the conflict with the pope, see María José Rodríguez Salgado, The Changing Face of Empire: Charles V, Philip II and Habsburg Authority, 1551-1559 (Cambridge: Cambridge University Press, 1989) 151-53.

21. See Michael J. Levin, "A New World Order: The Spanish Campaign for Precedence in Early Modern Europe," Journal of Early Modern History 6 (2003): 233-64, 238-41, and also his Agents of Empire: Spanish Ambassadors in Sixteenth-Century Italy (Ithaca: Cornell University Press, 2005), 28-29.

22. Antoine Perrenot de Granvelle, Papiers d'État du cardinal de Granvelle, d'après les manuscrits de la bibliothèque de Besançon, 9 vols. (Paris: Imprimerie Royale, 1841-52), 5:257. 
of Cateau-Cambrésis (3 April 1559). ${ }^{23}$ Initially, he considered the possibility of Vargas remaining at court with Margaret of Parma, together with Granvelle, ${ }^{24}$ but then decided, at the beginning of August, to send him as ambassador to the imperial court in Vienna. ${ }^{25}$ Finally that plan, too, changed with the arrival of the announcement of the death of the ambassador in Rome, Juan de Figueroa, which occurred on 28 July; Vargas was appointed ambassador in Rome-ambassador extraordinary, not ordinary-at the end of August. ${ }^{26}$ For this appointment, Vargas once again had the support of Granvelle: "If Your Majesty has not yet chosen some noble," he wrote on 5 August, while Philip was still deliberating, Vargas "would be ideal for expediting the business in hand that is being asked of Spain and these states [the Low Countries] right now, since he already has experience of affairs concerning Rome, he also knows what is going on in Italy and those who closely assist His Holiness there." ${ }^{\text {27 }}$ It is likely that, for this most important appointment of his career, Vargas also received the backing of Ruy Gómez de Silva, a member of the council of state and favourite of Philip II, particularly taking into consideration that the opposing faction at court, led by Fernando Álvarez de Toledo, duke of Alba, was taking steps for the appointment to be revoked in the following months (the duke had an interest in his own son becoming the ambassador ordinary of the kingdom in Rome).$^{28}$

\section{Constant, 362.}

24. This is assumed by Sébastien de l'Aubespine, French ambassador at the court of Philip II, in a letter dated 4 August to King Francis II; Louis Paris, Négociations, lettres et pièces diverses relatives au règne de François II (Paris: Imprimerie Royale, 1841), 66.

25. Constant, 363.

26. Constant, 363.

27. "Si Vuestra Majestad no escoge a algún señor, [...] [Vargas] sería muy a propósito para la expedición de los negocios que ahora se piden para España y para estos estados, teniendo él ya plática de las cosas de Roma y noticia de las de Italia y de las personas que cabe Su Santidad asisten” (Granvelle, 5:635); Constant, $363 n 3$.

28. Constancio Gutiérrez, Trento, un problema: la última convocación del Concilio (1552-1562), 5 vols. (Madrid: Universidad Pontificia de Comillas, 1995-2000), 4:77. For the Ebolist faction, see José Martínez Millán, "Grupos de poder en la corte durante el reinado de Felipe II: La facción ebolista, 1554-1573," in Instituciones y élites de poder en la Monarquía hispana durante el siglo XVI, ed. José Martínez Millán (Madrid: Universidad Autónoma de Madrid, 1992), 137-97; for the activity of Ruy Gómez in the Low Countries during 1558-59, although without reference to Vargas, see James M. Boyden, The Courtier and the King: Ruy Gómez de Silva, Philip II, and the Court of Spain (Berkeley: University of California Press, 1995), 78-82. 
Vargas established such a good relationship with Pope Paul IV during the months that he had spent in Rome a year before that the pope had spontaneously offered him a cardinal's hat. Vargas's wife, Inés de Villafañe, had already taken vows as a nun and Vargas himself had received Holy Orders at some point during his extended stay in Italy. The death of the pope on 18 August 1559 prevented the appointment from going through. ${ }^{29}$ His relationship with the next pope, Pius IV, was a stormy one. The tense negotiations concerning the resumption and development of the final stage of the Council of Trent led to a deterioration in that relationship, complete with shouting matches and dramatic scenes in the streets. ${ }^{30}$ These arguments were mentioned years later by Sforza Pallavicino, who censured the way Vargas defended the freedom of the general councils in the very presence of the pope and other ambassadors. ${ }^{31}$ Between 1560 and 1561, Pius IV repeatedly asked Philip II to withdraw him from the ambassadorial post and Vargas himself requested permission, from 1561 onwards, to be withdrawn from it because of continuing health problems and to be allowed to return to his own country and retire from political life; there is evidence that he was seriously ill between July and September $1562 .{ }^{32} \mathrm{To}$ replace Vargas, Philip II appointed Luis de Requesens, although the monarch postponed the latter's journey to Rome until October $1563 .{ }^{33}$ Vargas retired to the Hieronymite monastery of Santa María de Sisla in Toledo, where he died two years later. ${ }^{34}$

The intense diplomatic activity of Francisco de Vargas in Italy can be reconstructed from the large number of texts that he wrote-above all, those between 1551 and 1563 - and that have been preserved in European archives, parts of which have been edited in collections of texts on sixteenth-century diplomatic history or the history of the Council of Trent published during the nineteenth and twentieth centuries. Vargas was an expert on civil and canon law and wrote treatises and reports on matters of current interest, none of which was intended, in principle, to be printed. A manuscript report

29. Granvelle, 6:539.

30. Constant, 370-74, 377-78; Levin, Agents, 69-74; Pattenden, "From Ambassador to Cardinal?"

31. Sforza Pallavicino, Istoria del Concilio di Trento, 3 vols. (Milan: Giuseppe Marelli, 1745), 2:560.

32. Constant, 374-75.

33. Constant, 374.

34. Gutiérrez, Españoles en Trento, 486-89. 
on the reforms that should be undertaken at the Council of Trent (end of 1545), some Apuntamientos en la dirección del concilio y oficio del embajador (Notes on the way that the council should be managed and the office of the ambassador; March-April 1551), a report on the draft of the sacrament of Holy Orders studied at Trent (January 1552), and the previously cited report on the procedure to be followed in relation to a possible declaration of war on Pope Paul IV (1556) have been preserved. ${ }^{35}$ Reports and treatises that Vargas refers to in his correspondence, if indeed they were ever written, have been lost. These include texts on the authority of general councils and their history, on royal patronage, on the infallibility of the councils and the non-necessity of papal confirmation, on the right to conquer infidels, and on the canonization of saints by the pope. ${ }^{36}$ The only text to reach the printer was a treatise on the jurisdiction of the bishops (De episcoporum iurisdictione et de pontificis maximi auctoritate responsum, Rome: Paolo Manunzio, 1563), written at the behest of Pope Pius IV in the summer of 1563, when the divine foundation of the residency of bishops was being debated at Trent. In that treatise, Vargas defended the argument that the power of jurisdiction of the bishops depended on the pope, not on Christ, which, as I shall go on to explain in this article, was the exact opposite position that he had sustained throughout his diplomatic career, as Michael Geddes already pointed out in $1697 .{ }^{37}$

35. Constancio Gutiérrez, "Memorial de Francisco de Vargas sobre reforma. Año 1545," in Reformata Reformanda: Festgabe für Hubert Jedin zum 17.Juni 1965, ed. Erwin Iserloh and Konrad Repgen (Münster: Aschendorff, 1965), 531-76; Constancio Gutiérrez, "Nueva documentación tridentina (Continuación)," Archivium Historiae Pontificiae 2 (1964): 211-50; reprinted with additions in Trento: un concilio, 1:202-30 (I always quote from this edition). The report on Paul IV is preserved in manuscript form in the Biblioteca Nacional de España, MSS 19011, fols. 111r-184v.

36. Gutiérrez, Trento: un concilio, 1:215 (on the authority of the councils); 2:131 (on royal patronage); Granvelle, 6:478 (on the infallibility of the councils and non-confirmation by the pope); Vargas, De episcoporum iurisdictione, 103 (on the right to conquer infidels); 109 (the canonization of saints by the pope).

37. Michael Geddes, History of the Council of Trent (London: B. Barker, 1714), 77. The reason for this change in doctrinal position is not yet clear, although I consider two hypotheses, which are not necessarily mutually exclusive: the first would be the desire to check the episcopalism displayed by some Spanish prelates led by the archbishop of Granada, Pedro de Guerrero, at Trent, insofar as episcopalism threatened the implementation of Philip II's regalian policy (the coexistence of episcopalism and regalism in the same author became unsustainable after the conclusion of the Council of Trent; for the case of Pedro Guerrero, see Fernández Terricabras, Felipe II, 55-57, 254-55); the second possibility 
The best known set of documents by Vargas are theletters and reports that he wrote to Antoine Perrenot de Granvelle during the second period of the Council of Trent (1551-52). This collection of documents was acquired by William Trumbull, an English diplomat who served as first secretary of the embassy of James I of England during the Twelve Years' Truce between the Habsburg rulers of Spain and the Southern Netherlands, and the Dutch Republic (1609-21). ${ }^{38}$ His grandson, William Trumbull, entrusted the documents to the bishop and theologian Edward Stillingfleet, who commissioned an English translation of the texts from the historian Michael Geddes (1697). ${ }^{39}$ Three years later, in 1700, Michel Le Vassor, a convert to Protestantism exiled in England, published a French version of the texts with a dedication to Trumbull's grandson. ${ }^{40}$ Le Vassor's text was published shortly afterwards in a Latin translation by Konrad Schramm (1704) ${ }^{41}$ Vargas's texts, with his criticism of the lack of freedom of the council, served to confirm the Protestant view of a Catholic church tyrannized by the pope. The editions of Geddes and Le Vassor triggered several attempts at refutation from the Catholic world, such as the critique published by Jean Frain du Tremblay (1719) — who examined Vargas's work together with Paolo Sarpi's Istoria del Concilio Tridentino-and the anonymous Spanish translation of the letters with annotations by the editor, which set out to salvage the orthodoxy

would be the result of a strictly personal doctrinal development in Vargas's life, stemming from the general ascendancy of Jesuits like Diego Laynez or Francisco de Borja, after Vargas arrived in Rome in 1559. For Vargas's correspondence with Laynez, see Feliciano Cereceda, Diego Laínez en la Europa religiosa de su tiempo 1512-1565, 2 vols. (Madrid: Ediciones Cultura Hispánica, 1946), 2:50-55.

38. For the history of this collection, see Henry Outram Evennett, "The Manuscripts of the VargasGranvelle Correspondence, 1551-52," The Journal of Ecclesiastical History 11.2 (1960): 219-24; Constancio Gutiérrez, "Nueva documentación tridentina 1551-1552," Archivium Historiae Pontificiae 1 (1963): 179-240.

39. The Council of Trent no Free Assembly, More Fully Discovered by a Collection of Letters and Papers of Dr. Vargas and Other Ministers, published from the Original Mss. (London, 1697). The text was reissued in 1714.

40. Lettres et memoires de François de Vargas, de Pierre de Malvenda et de quelques évéques d'Espagne touchant le Concile de Trent (Amsterdam: Pierre Brunel, 1700). The text was reissued in 1720.

41. Francisci de Vargas, Petri Malvuenda, veterumque quorundam Hispaniae episcoporum de concilio Tridentino epistolae et observationes, quas ex Hispanico primum, quo scriptae erant pleraeque, in Gallicum sermonem traduxerat notisque illustraverat vir clarissimus Michael Vassorius, ob usum in historia illius praecipue aetatis ac testimonium quod praestant indubitatum latina lingua omnes fideliter ac studiose adornatae (Brunswick: Christoph Friedrich Fickel, 1704). 
of the original (ca. 1765). ${ }^{42}$ Vargas's refutation published by Jean Frain du Tremblay was translated years later by Francesco Santoni (1792) in response to the favourable treatment given to Vargas's documents in a posthumous work by the Jesuit, Francisco Xavier Maestre (1790). ${ }^{43}$

As this collection of documents circulated in the seventeenth, eighteenth, and nineteenth centuries, the figure of Vargas became associated with criticism of papal power and defense of the freedom of the council. The most complete account of his ideas on the topic can be found in the previously mentioned Apuntamientos addressed to Antoine Perrenot de Granvelle. After the death of his father, Nicolas Perrenot de Granvelle (1550), Antoine inherited his responsibilities at court and became the most important of Charles V's advisers on affairs related to the Low Countries, the empire, France, and England. ${ }^{44}$ Vargas wrote the report in Trent between March and April 1551, a few weeks before the beginning of the second stage of the council on 1 May, and sent it to Augsburg, where the imperial court was located at the time. ${ }^{45}$ It is possible that Granvelle himself asked Vargas to write this report, the purpose of which was to warn of the need for the imperial ambassador to take a more active role in the ongoing conciliar discussions. Vargas points out that the papal legates controlled the agenda of issues to be discussed during the first stage of the

42. Critique de l'histoire du Concile du Trente de Fra Paolo, des lettres et des memoires de Vargas (Rouen: Guillaume Behourt, 1719); Cartas de Francisco de Vargas, de Pedro Maluenda y de otros prelados de España sobre el Concilio de Trento, traducidas del original castellano al francés por Miguel Le Vassor, y restituidas al castellano por un bibliófilo con notas y contranotas, las primeras de Vassor, y las segundas del bibliófilo. The manuscript of this translation has been preserved in the Seminario Mayor de Granada, sign. 9.3.4; see Gutiérrez, Trento: un concilio, 1:17-18. I have not been able to consult this manuscript.

43. Francesco Saverio [Xavier] Maestre, Della maniera di pensare degli spagnoli nelle cose religiose e delle liberta delle Chiesa di Spagna, opera postuma (Florence: Giacopo Grazioli, 1790); Riflessione critiche sopra la memoria e lettere di Francesco de Vargas, consigliere dell' ambasceria cesarea e regia di Spagna al Concilio di Trento, tradotte dal francese ed arricchite d'annotazioni per servire d'antidoto contra il veleno sparso ad oltraggio d'esso concilio nell'opera di Francesco Severio Maestre sivigliano stampata in Firenze 1790 (Trento: Giambattista Monauni, 1792).

44. Marco Legnani, Antonio Perrenot de Granvelle: Politica e diplomazia al servizio dell'impero spagnolo (1517-1586) (Milan: Edizioni Unicopli, 2013), 40. In 1550, he had been appointed vice president of the Palatine Council in the Empire, see Alfred Kohler, Carlos V, 1500-1558. Una biografía (Madrid: Marcial Pons, 2000), 131.

45. Vargas refers to the sending of this report in a letter dated 26 November 1551, addressed to Granvelle himself (Gutiérrez, Trento: un concilio, 1:556). 
council, which, according to Vargas, ran counter to the practice at past councils. It was more than likely that this would occur again in this second stage. The imperial ambassador was the only representative of the emperor, Charles V, who had the right to attend the preparatory meetings (known as classes and congregations), which was where matters that would be put to the vote later in the sessions were debated. The role of the imperial ambassador, therefore, was essential for ensuring that the necessary church reform was implemented and the interests of the empire and the rest of Charles V's dominions were protected. In writing the report, Vargas was thinking of the performance of the imperial ambassadors, Diego Hurtado de Mendoza and Francisco de Toledo, during the first period of the council. Without mentioning them by name, Vargas was reproaching them for not having been sufficiently active in the congregations mentioned and for having been absent from the council at moments that were important for the imperial side, such as when the decree on justification was published (session 6, 13 January 1547) or when the legates moved the council to Bologna (session 8, 11 March 1547). ${ }^{46}$

The Apuntamientos begin with a short history of the ecumenical councils and an ecclesiological definition of the grounds for their existence. The ecclesiology of Vargas is based on the Haec sancta decree, promulgated at the fourth and fifth sessions of the Council of Constance (30 March and 6 April 1415). That decree asserted the authority of the general councils over the popes and its main objective was to grant the council the necessary authority to end the Western Schism. ${ }^{47}$ Hence, for Vargas, the general council

46. Gutiérrez, Trento: un concilio, 1:229 and 226 (modernized spelling has been used in all quotations from this and other editions of texts by Francisco de Vargas, as long as modernization does not involve altering the phonetics of the original). Diego Hurtado de Mendoza was appointed Imperial ambassador for Trent on 20 February 1545, although the council did not start until December. On 15 March 1546, the second ambassador, Francisco de Toledo, arrived in Trent. Hurtado de Mendoza left the position after he was appointed ambassador to Rome on 29 August 1546. In the second period of the council, there were three ambassadors: Hugo, count of Montfort, representing the empire; Francisco de Toledo, representing Castile and Aragon; and Guillaume de Poitiers, representing Flanders and Burgundy. Toledo was the one who bore the weight of the negotiations and signed most of the dispatches with the emperor. Gutiérrez, Españoles en Trento, 443; Hubert Jedin, Storia del Concilio di Trento, 4 vols. (Brescia: Morcelliana, 1949-1981), 2:567.

47. "First it declares that, legitimately assembled in the holy Spirit, constituting a general council and representing the catholic church militant, it has power immediately from Christ; and that everyone of whatever state or dignity, even papal, is bound to obey it in those matters which pertain to the faith, the 
"truly represents the universal Church" and receives its authority "directly from Christ." ${ }^{\prime 8}$ He points out that "once lawfully assembled by the pope," the fundamental thing about the general council is "the freedom with which all matters of faith and practice have to be dealt with [...] so that, whatever is defined here is understood as inspired by the Holy Spirit." ${ }^{49}$ Hence, the general council is infallible and cannot err in its decisions "from the very moment that they are decreed, because they are dictated by the Holy Spirit." ${ }^{50}$ On this point, "whatever conclusions were reached in the general councils, were ordered to be kept irrefragably, tamquam inviolata authoritas, because confirmation by the Supreme Pontiffs was not necessary to validate them." ${ }^{51}$ Vargas adds with irony that "neither the pope on his own nor together with the college of cardinals" was ever seen to lay claim to this confirmation with the expression "Visum est Spiritui Sancto et nobis." ${ }^{2}$ It was the synod council that "guided it and ordered it," "with jurisdiction in matters decided by the Fathers." ${ }^{33}$ So, for example, "the authority to appoint" presidents of the council did not fall to the pope, but to "the body of the council." 54 This conciliar ecclesiology was based on "reasons and authorities of divine law," was "established at the Council of Constance," and "was clearly seen in the Apostolic councils, where, even though Saint Peter

eradication of the said schism and the general reform of the said church of God in head and members," Decrees of the Ecumenical Councils, ed. Norman Tanner, Giuseppe Alberigo, et al., 2 vols. (London and Washington, DC: Sheed and Ward-Georgetown University Press, 1990), 1:409. Hereafter, Decrees.

48. "representa verdaderamente la Iglesia universal" (Granvelle, 6:471); "la autoridad del concilio, que tiene inmediatamente de Cristo" (Gutiérrez, Trento: un concilio, 1:225).

49. "Lo esencial del concilio universal-después de legítimamente congregado-es la libertad con que todas las materias de fe y de costumbres se han de tratar [...] para que lo que así fuere definido, se entienda inspirado por el Spíritu Santo" (Gutiérrez, Trento: un concilio, 1:213).

50. "tienen infaliblidad sin poder errar [...] desde el mesmo punto que se decretan, porque dicta el Spíritu Santo” (Granvelle, 6:476).

51. "lo que en los concilios universales se fenescía, irrefragablemente se mandaba guardar tamquam inviolata authoritas, porque la confirmación de los Sumos Pontífices no era necesaria para la validación” (Gutiérrez, Trento: un concilio, 1:209).

52. "jamás papa por sí ni junto con el colegio de cardenales se arrogó: Visum est Spiritui Sancto et nobis" (Gutiérrez, Trento: un concilio, 1:213).

53. "la misma sínodo es la que todo lo guiaba y ordenaba" (Gutiérrez, Trento: un concilio, 1:211); "había jurisdicción en los padres” (Granvelle, 6:496).

54. "esta autoridad de nombrar personas que hiciesen aquel oficio [...] que llamaban presidentes [...] quedaba en el mismo cuerpo del concilio" (Gutiérrez, Trento: un concilio, 1:212). 
was prince and universal shepherd of the Church," it could be seen that "all power lay with the body of the council.", 55

The meaning and scope of the Haec sancta decree has been subject to interpretation ever since the fifteenth century..$^{56}$ The Council of Basel defended its dogmatic nature for the purpose of justifying the reform of the Roman Curia and deposing Pope Eugenius IV himself. ${ }^{57}$ Those in favour of a papal monarchy, starting with Juan de Torquemada and his Summa de ecclesia (ca. 1453), challenged the legal and dogmatic validity of the decree..$^{58}$ The brief history of the general councils that Vargas sketches in his Apuntamientos is clearly situated in the battle to impose an account of what happened during the councils of Constance and Basel. ${ }^{59}$ For Vargas, the ecumenical nature of the Council of Constance- "highly renowned and of great utility to the Christian republic"is irrefutable,${ }^{60}$ and he makes the same assertion in the Apuntamientos about the first twenty-five sessions of the Council of Basel (from 14 December 1431 to 7 May 1437), until the moment when Eugenius IV decided to continue the council in Ferrara (8 January 1438). ${ }^{61}$ Concerning the second period of this council, which developed in parallel in Basel on the one hand, and in Ferrara, Florence, and Rome on the other, Vargas does not take an explicit position, although he does acknowledge that "of necessity, one of them was not lawful."62

55. "Lo cual, aliende de las razones y autoridades de derecho divino y de estar determinado en el Concilio de Constanza, se ve claramente en los concilios de los Apóstoles, donde, aunque sant Pedro era príncipe y pastor universal en la iglesia, [...] [se ve] que en el cuerpo del concilio estaba todo el poder" (Gutiérrez, Trento: un concilio, 1:211).

56. For an assessment of the bibliography on the decree, see Gerald Christianson, "Conciliarism and the Council," in A Companion to the Council of Basel, ed. Michiel Decaluwé, Thomas M. Izbicki, and Gerald Christianson (Leiden: Brill, 2017), 75-111.

57. Joachim W. Stieber, Pope Eugenius IV, the Council of Basel and the Secular and Ecclesiastical Authorities in the Empire: The Conflict over Supreme Authority and Power in the Church (Leiden: Brill, 1978), 44-56.

58. Thomas Izbicki, "Papalist Reaction to the Council of Constance: Juan de Torquemada to the Present," Church History 55 (1988): 7-20.

59. Nelson Minnich, "Councils of the Catholic Reformation: A Historical Survey," in The Church, the Councils, and Reform: the Legacy of the Fifteenth Century, ed. Gerald Christianson, Thomas Izbicki, Christopher M. Bellito (Washington, DC: Catholic University of America Press, 2008), 27-59.

60. "muy célebre y de grande utilidad a la república cristiana" (Gutiérrez, Trento: un concilio, 1:204).

61. Gutiérrez, Trento: un concilio, 1:205.

62. "de necesidad el uno no fue legítimo" (Gutiérrez, Trento: un concilio, 1:205). In other texts, Vargas records that for some contemporaries, not even the first part of the Council of Basel was an ecumenical 
For Vargas, the Council of Basel had been the last ecumenical council held by the church. He did not consider that the Fifth Lateran Council (1512-17), convened in reaction to the Council of Pisa (1511), was an ecumenical council but an "economic" council, in the sense of domestic, because it was held in Rome under the presidency, first of Julius II and then of Leo X, and dealt only with the private interests of the Holy See. ${ }^{63}$ According to Vargas, ultimately, the council was conceived as an attack on the doctrine "of the authority of the council over the pope", in other words, an attack on the councils of Constance and Basel. ${ }^{64}$ The resolutions of the Fifth Lateran Council however could not alter "the truths decided by other councils-most notably by the one in Constance," nor could it "make what was once true and dictated by the Holy Spirit cease to be so." $^{65}$ In this context, Vargas was thinking specifically of the bull Pastor aeternus (1516), which reasserted the supremacy of the pope over the council. ${ }^{66}$

Vargas's texts shed light on two ecclesiological positions clearly opposed to each other in relation to the nature of the general council: on the one hand, the position led by the Dominicans, Juan de Torquemada and Tomasso de Vio, also known as Thomas Cajetan, who defended the superiority of the pope over the council ${ }^{67}$ and on the other, the position held by Pierre d'Ailly, Nicholas de Cusa, and Alonso de Madrigal, known as "El Tostado," who maintained the

council; Gutiérrez, "Memorial de Francisco de Vargas," 547; Granvelle, 6:499.

63. Gutiérrez, Trento: un concilio, 1:206. As Gutiérrez points out, several bishops had also refused to include this council among the ecumenical ones (CT, 1:127).

64. "lo que allí [Constanza] se determinó de la autoridad del concilio al papa. Contra el cual [Constanza], por esta razón, y contra el Basiliense hizo León Décimo el concilio Lateranense segundo” (Gutiérrez, Trento: un concilio, 1:206).

65. Gutiérrez, Trento: un concilio, 1:207.

66. "For it is clearly established that only the contemporary Roman pontiff, as holding authority over all councils, has the full right and power to summon, transfer and dissolve councils" (Decrees, 1:642). Significantly, when Pius IV tried to convince Vargas in 1560 of his good faith in relation to the resumption of the council, he told him that "it would not be a Lateran council" (Gutiérrez, Trento, un problema, 4:22).

67. Thomas Izbicki, Protector of the Faith: Cardinal Johannes de Turrecremata and the Defense of the Institutional Church (Washington, DC: The Catholic University of America Press, 1981); Olivier de la Brosse, Le Pape et le Concile. La comparaison de leurs pouvoirs à la veille de la Réforme (Paris: Éditions du CERF, 1965); Conciliarism and Papalism, ed. James H. Burns and Thomas M. Izbicki (Cambridge: Cambridge University Press, 1997). 
council had superiority over the pope. ${ }^{68}$ Vargas did not write any treatise on the general council, so that these two ecclesiological positions were neither presented nor compared in an articulated form. Nevertheless, the quotations taken from these authors and his own comments enable us to reconstruct his perception of European ecclesiological tradition on this subject. ${ }^{69}$ Bearing in mind that the works of other Castilian conciliarists like Juan de Segovia or Juan González de Sevilla faded into oblivion as soon as the Council of Basel was concluded, it is important to highlight the role that Alonso de Madrigal must have played in transmitting and legitimizing conciliar ideas in sixteenthcentury Iberian intellectual circles, a role probably linked to the fact that his work was the only one that circulated in printed form.

For the Holy See and its legates, conciliarism was a threat that ran through the three periods of the Council of Trent. As John O’Malley has pointed out "Pisa, Constance, and Basel had not been forgotten, and the question of the relationship between pope and council [...] was destined to be a major issueunder-the issues." ${ }^{70}$ Specifically, the papacy's fear was that, once the council was lawfully assembled, it would cease to recognize the authority of the pope and would undertake a reform of the head of the church. There were good reasons for fearing that the council would drift towards a reform of these characteristics.

68. Francis Oakley, The Political Thought of Pierre d'Ailly: The Voluntarist Tradition (New Haven and London: Yale University Press, 1964); Morimichi Watanabe and Thomas Izbicki, "Nicholas of Cusa: A General Reform of the Church," in Nicholas of Cusa on Christ and the Church, ed. Gerald Christianson and Thomas Izbicki (Leiden: Brill, 1996), 175-202; and Jesse Mann, "Alfonso de Madrigal and Juan de Segovia: Some Conciliar Common (and Contested) Places," included in this special issue.

69. The following are the most significant references to these authors in Vargas's work: Gutiérrez, Trento: un concilio, 1:210-11 (Torquemada, Summa de ecclesia, 3.32; 3.15; 2.5 and 14); 1:212 (Tomasso de Vio, De divina institutione pontificatus Romani pontificis, 5); 1:208, 213, 228 (Nicholas of Cusa, De concordantia catholica, 2.2, 2.3, 2.16); 1:211, 213 (Madrigal, In defensorium trium conclusionum, 2. c.72; In evangelium Matthaei, Praefatio, q. 10). For generally positive references to the treatise of Pierre d'Ailly, see Gutiérrez, "Memorial de Francisco de Vargas," 547 and 563. For other references defending the superiority of the pope (Niccolò de'Tudeschi, Torquemada, Cajetan), see, for example, Granvelle, 6:475, $481,487,519$. In order to refer to the authority of the council for electing presidents, Vargas quotes the sources adduced by Domenico Giacobazzi, De concilio tractatus (Rome: Antonius Bladus, 1538), 21, specifically references of Giovanni d'Andrea, Baldo degli Ubaldi, Martinus Garatus Laudensis. See Gutiérrez, Trento: un concilio, 1:212; Granvelle, 6:490, 496.

70. John W. O’Malley, Trent: What Happened at the Council (Cambridge, MA and London: Harvard University Press, 2013), 80. 
The openly conciliar positions of the Protestants and the Gallican church, the well-known desire for reform of the Spanish prelates, and Charles V's interest in increasing his control over the churches of his respective dominions were questions of enormous concern to the papacy. Time and again, the correspondence of the papal agents returned to these issues. Octaviano della Rovere, for example, Bishop of Terracina and papal nuncio at the Court of Philip II (1560-61), warned Pius IV on 16 June 1561, as the council was about to resume at Trent, that "all the French and Germans were in agreement that the council was above the pope, and so were many of the Spaniards and even the Italians."71 Eight months later, on 19 February 1562, the cardinal and papal legate Ludovico Simonetta wrote from Trent to Charles Borromeo that "the Spaniards had told the ambassadors of Caesar that, once the council started, all the authority of the pope ceased and the legates did not have the right to proposal."72

Vargas was very much looking forward to the Council of Trent implementing the reform of the church that the papal agents were afraid of: an in-depth reform of the Roman Curia and, closely connected with that, reform of the church of Castile. The conciliar model for this reform was the Council of Constance. Vargas considered that the reform of the church envisioned at Constance had still not been implemented. Here Vargas was thinking specifically of session 40 of that council (30 October 1417), where eighteen articles were listed that the council together with the pope had to implement in order to "reform the Church in its head and in the Roman Curia." ${ }^{73}$ Nevertheless, this reform projected at Constance "was never carried out, except for some articles." ${ }^{74}$ In the context of this envisioned reform, France was the model to be

71. "todos los franceses y alemanes estaban en que el concilio era sobre el papa, y muchos de los españoles y aun de los italianos" (Gutiérrez, Trento, un problema, 5:89; see also 5:65). The idea went back a long way, as can be seen in a 1531 report by Bishop Uberto Gambara, CT, 4:lxii.

72. "Li Spagnoli havevano detto alli ambasciatori Cesarei che aperto il concilio cessava ogni auttorità del papa et che le propositioni non toccavano alli legati” (Die Römische kurie und das konzil von Trient unter Pius IV, ed. Josef Susta, 4 vols. [Vienna: Aldred Hölder, 1909]: 2:29).

73. Decrees, 1:444. For the reform planned at session 40 of Constance, see Giuseppe Alberigo, Chiesa conciliare. Identità e significato del conciliarismo (Brescia: Paideia, 1981), 229-30; O’Malley, 27. On the reforms undertaken at Constance, see Phillip H. Stump, The Reforms of the Council of Constance (1414-1418) (Leiden: Brill, 1994), 51-169.

74. "una reforma que no se efectuó, salvo en algunos artículos" (Gutiérrez, "Memorial de Francisco de Vargas," 547). 
followed, with respect both to the implementation of royal patronage and to the degree of autonomy of the Gallican church. For Vargas, therefore, the Pragmatic Sanction of Bruges approved at the Council of Basel (1437) and especially the Concordat of Bologna (1517) were two agreements to be borne in mind in the context of the negotiations between the Spanish prelates and imperial agents with the pope and his legates. ${ }^{75}$

Vargas's correspondence, both as adviser to the imperial ambassador at Trent (1545-48, 1551-52) and as Philip II's ambassador in the Roman Curia (1559-1563), shows his firm commitment to this vision of reform. The interest that his texts aroused among late seventeenth-century Protestants such as Geddes and Le Vassor is eloquent in this respect. Nevertheless, the council was prevented from moving in that direction by the way in which the management of the Council of Trent was planned, with the legates controlling the agenda of topics for discussion. The determination of the legates to defer or pass over items of business related to church reform was a constant during the three periods of the council. As Vargas wrote, "the pope and his ministers would rather have their throats cut" than do anything that they think might lead to their "losing one iota of their ambitions." ${ }^{\prime 6}$ The only way to achieve any of the envisioned objectives in terms of reform was to appear compliant with the legates as well as the pope and to realize that the objectives would only be achieved in the long run: "I answered him by placating him, to reassure him," Vargas wrote to Philip II after a difficult conversation with Pius IV in September 1561, "without touching on matters that will be borne out by events later."77

Vargas was adapting to a course of action laid down by Charles $V$ himself and followed by Philip II years later concerning negotiations on topics of reform with the legates at the council. ${ }^{78}$ On 7 February 1546, as soon as the

75. Gutiérrez, "Memorial de Francisco de Vargas," 554 (Concordat); Gutiérrez, Trento: un concilio, 1:446-48 (Pragmatic and Concordat).

76. "primero el Papa y sus ministros se dejarán degollar, que hagan cosa por do piensen perder un punto de sus pretensiones" (Gutiérrez, Trento: un concilio, 2:86).

77. "respondile contemporizando por aseguralle y sin tocar en cosas que el suceso las dirá después" (Guerrero, Trento, un problema, 5:232; see also 5:404).

78. For the development of diplomacy as a result of diplomatic activity in Italy, see Isabella Lazzarini, Communication and Conflict: Italian Diplomacy in the Early Renaissance, 1350-1520 (Oxford: Oxford University Press, 2015); Catherine Fletcher, Diplomacy in Renaissance Rome: The Rise of the Resident Ambassador (Cambridge: Cambridge University Press, 2015). 
council started, the emperor warned Juan de Pacheco from Arnhem that, in order to predispose Paul III towards reform, it was necessary to please "His Holiness in all matters that do not go against the authority of the Council." ${ }^{19}$ On 8 October 1551, Charles asked the imperial ambassador, Francisco de Toledo, to schedule the least important items first, and always stressing that the aim was not to diminish the authority of his Holiness, "which is what they are most afraid of, as you well know." ${ }^{80}$ Once the confidence of the legates had been won, that would be the moment to gradually introduce questions related to the abuses that lay at the heart of the reforms made by the Protestants. Matters that affected the authority of the Holy See-residency of the cardinals, ecclesiastical benefices, dispensations-should be left for a more advanced stage of negotiations. As Granvelle noted in a letter that same fall, "anyone who talked about correcting ad exactum every single abuse in the Roman Curia would waste the whole business with nothing to show for it." ${ }^{\prime 1}$ In this respect, one of the functions of the imperial agents at Trent was to control the prelates from the Habsburg dominions who were the most demanding in the need to put an end to the abuses, so as to prevent them from launching inopportunely into these questions "in a strict and harsh manner." ${ }^{82}$ Vargas himself writes that the role of the ambassador was precisely to negotiate with the legates and prelates to achieve the best possible terms-"he must show great skill and modesty when negotiating" - with the final objective of fulfilling the political agenda of Charles V. ${ }^{83}$

The need not to upset the papal legates did not mean that Vargas was renouncing his ecclesiological principles concerning general councils. The fact

79. "satisfacer generalmente a Su Santidad en todas aquellas cosas que no fueren contra la autoridad del concilio" (El Concilio de Trento, 1:55). In the same letter he uses the word "contemporizar" to signal the need to prolong the deliberations on doctrine with the legates in order to give the Protestants time to arrive at the council (56).

80. "que es lo que ellos, como vos sabéis bien, más temen" (Gutiérrez, Trento: un concilio, 1:428; see also 2:241).

81. "Quien hablase de corregir ad exactum exactamente todos los abusos que hay en la Curia romana, sería perder el negocio sin algún fructo" (Gutiérrez, Trento: un concilio, 1:508); the same idea is found in a 1560 report on the council by the archbishop of Seville, Fernando de Valdés (Gutiérrez, Trento, un problema, 4:113).

82. "no quieran entrar con tanto rigor y aspereza en estos principios" (Gutiérrez, Trento: un concilio, $1: 428)$.

83. "ha de tener toda dexteridad y modestia en el negociar" (Gutiérrez, Trento: un concilio, 2:229). 
that the Council of Trent was not functioning with the freedom that ought to be the norm at all general councils was a temporary state of affairs as far as Vargas was concerned. In January 1562, as the third stage of the council was commencing, he wrote that universal councils "have declined to what can be seen [today]," but "it is necessary to give them back the authority that they have lost" because they are "the sacred anchor and final remedy that the Church has always used for its maladies." ${ }^{84}$ Although Vargas expresses concern for the precedent that this council would represent for future general councils, he continued to regard the authority of the council over the pope as decreed at Constance and ratified at Basel as incontrovertible from a dogmatic point of view. The council of Trent has in effect been subjected to the authority of the pope, but this did not mean, he wrote in December 1563 when it was over, that the legates have in the end "given authoritative approval to the superiority of the pope over the council, and that this one and all those that are or were universal count for nothing, or have no authority or jurisdiction other than that which the pope wishes and grants them." ${ }^{85}$ In this respect, when he discovered in January 1552 that the legates were in fact trying to establish by decree that the pope did have precedence over the general council, his reaction is significant.

The episode occurred in the context of preparations for the passing of the decree and the canons on the sacrament of the order at the fifteenth session of the council, scheduled for 25 January 1552. On 3 December 1551, a series of sentences by Protestant authors-Bucer, Calvin, Luther, Melanchthon, Zwingli-had been supplied for examination by the theologians (around seventy in number) in the congregations. ${ }^{86}$ The theologians discussing the sacrament of order unanimously rejected the assertions that the order was not a sacrament and that all Christians were priests, as the Protestants maintained.

84. "los concilios universales (que son la sacra áncora y último remedio de que la Iglesia siempre usa en los males) han venido en la declinación que se ve, y que mucho más agora [...] se debe volver por su auctoridad" (Granvelle, 6:500-01).

85. "los legados pensarán haber canonizado lo de la superioridad del papa al concilio y de que este y cuantos son universales o fueron, no valen nada, ni tienen autoridad, ni jurisdicción, sino la que el papa quisiere y les diere, con nunca osallo decir ni proponer abiertamente, sabiendo el escándalo que darían al mundo y la burla que se haría de todo" (Dokumente zur Geschichte Karl's V., Philipp's II. und ihrer Zeit aus Spanischen Archiven, ed. Johann Joseph Ignaz von Döllinger [Regensburg: George Joseph Manz, 1862], 549-50).

86. Gutiérrez, Trento: un concilio, 3:216. Speeches in the congregations started on 7 December and went on until 29 December, with a break for Christmas between 24 and 28 December. 
The general congregations of prelates with voting rights began on 2 January 1552. To save time, it was agreed to carry out a simultaneous examination of Protestant ideas and to prepare a draft of the doctrine on the topic. ${ }^{87}$ The draft, drawn up directly by the papal legates, or under their supervision, included a chapter "on the Church hierarchy and on the difference between bishops and presbyters." ${ }^{88}$ The chapter considered an analogy between divine power and papal power and a defense of the exclusive authority of the pope as far as the concession of ecclesiastical benefices was concerned:

Just as that [heavenly Jerusalem] maintains various different levels of servants under one supreme governor, so also the visible Church of Christ has as its single supreme head on Earth its own supreme Vicar, through whose administration all the offices are distributed to all the remaining members in such a way that each one of the obligations shared out among their respective orders and places is carried out for the good of the whole Church with the maximum peace and unity. ${ }^{89}$

Vargas points out in a letter to Granvelle dated 20 January that he was the first to realize the doctrinal implications of that text: "nobody realized this until I warned of it and told Don Francisco and anyone who seemed appropriate."90 Francisco de Toledo confirms this view of events. As Toledo indicates, after talking to Vargas about the content of that clause, he would have ordered Salvador de Alepús (Archbishop of Sassari) to protest against it as a member of

87. Gutiérrez, Trento: un concilio, 3:217.

88. "De ecclesiastica hierarchia et episcopi ac presbyteri differentia" (Gutiérrez, Trento: un concilio, 2:33; Gutiérrez has edited the entire draft text, 20-41). See Jedin, Storia, 3:498n26.

89. "Nam ut illa sub vno supremo rectore uarios et diuersos ministrantium continet ordines, ita uisibilis Christi ecclesia summum ipsius Vicarium pro vnico et supremo capite in terris habet; cuius dispensatione sic reliquis omnibus membris officia distribuuntur, ut suis quaeque in ordinibus et stationibus collocata munera sua in totius ecclesiae utilitatem cum maxima pace et unione exequantur" (Gutiérrez, Trento: un concilio, 2:34; I have corrected exequatur to exequantur).

90. "ninguno caía en esto hasta que lo advertí y dije a don Francisco y a quién pareció convenir" (Gutiérrez, Trento: un concilio, 2:133; Vargas added a copy of the clause cited in an appendix). He repeated the same idea in another later letter to Granvelle, 2:149. Angelo Massarelli's diary does not cite any speech in opposition to this clause, either in the bishops' congregations (January 3-14) or in the sub-committee constituted to draw up the final draft of the doctrine and canons (January 15-19). See CT, 7:440-61. 
the sub-committee that would prepare the canons and final text of the doctrine on the sacrament between 15 and 19 January. According to both Toledo and Vargas, the other Spanish prelates on the sub-committee seconded the protest of Alepús, including Francisco Manrique de Lara (Bishop of Orense), who is said to have been accused of heresy by the legate for questioning that "the pope is above the council."91 Sources in papal circles also confirm the involvement of Vargas in this episode. Pietro Camaiani, the envoy of Pope Julius III at the Court of Charles V in Innsbruck, wrote weeks later on the subject of this clause that Vargas had tried to bribe the prelates to vote against it and criticized Vargas for showing a lack of respect toward the authority of the Apostolic See. ${ }^{92}$

Vargas examined this passage in several of his letters and in a Latin document that was published for the first time by Michael Geddes in his The Council of Trent. ${ }^{93}$ According to his interpretation of the passage, the text granted less authority to Christ than to the pope from the moment when Christ was presented as "governor" (rector) and the pope as "head" (cabeza). Whoever is granted the title of "head," writes Vargas, is awarded "power, influence, and superiority, while making all the lower members absolutely and necessarily dependent and bound to him," whereas it can only be said of a governor that he has "superintendence and superiority." ${ }^{94}$ Christ, he continues, is the supreme head of the heavenly and the visible church, because all things in both churches

91. "[el Legado] quiere determinar la quistión de que el papa es sobre el concilio. [...] El de Orense dijo que estaba dubdoso. [...] [el Legado le dijo]: El que duda en la fe, hereje es" (Gutiérrez, Trento: un concilio, 2:131; see also 194).

92. Nuntiaturberichte aus Deutschland : nebst ergänzenden Aktenstücken 1. Abteilung 1533-1559, 17 vols. (Gotha, Berlin, Frankfurt, Tübingen: F.A. Perthes, A. Bath, 1892-1970), 12:192. Camaini met Vargas in Innsbruck, where Vargas had been sent as Francisco de Toledo's envoy between 1 and 16 February.

93. Geddes, 242-47, who attributes it to Vargas. Gutiérrez, Trento: un concilio, 2:47-48 has edited the text, but does not attribute it to him, although he recognizes that it could be the author's because of the content. A comparison of Vargas's arguments in his correspondence with this text confirms that Vargas was the author.

94. "Adde quod plus uidetur tribuere Summo Pontifici quam Deo; nam Deum appellat summum rectorem, Pontificem autem summum et suppremum caput. Imo plus videtur dicere qui dicit summum caput, quam qui summum rectorem. Nam qui capitis nomen tribuit, subinde tribuere uidetur regimen, influentiam, superioritatem, et absolute necessariam dependentiam et colligantiam omnium membrorum inferiorum ad ipsum; qui autem rectorem dicit, solum dicit superintendentiam et superioritatem" (Gutiérrez, Trento: un concilio, 2:49-50; the same idea, with the same wording, can be found in his letter to Granvelle of 20 January, 2:132). 
depend on Him. ${ }^{95}$ The pope only has ministerial powers, the powers that belong to the governor: limited powers, because God only gave Peter and the other apostles the power to build the church, not to destroy it. ${ }^{96}$ Hence, Vargas warns that the statement in the text according to which the pope was the only supreme head on Earth "virtually" implied decreeing that the pope had authority over the general council..$^{97}$

The text, continues Vargas, also states that the pope has supreme power to dispense and distribute all ecclesiastical benefices, which implicitly denies that "any bishop or prelate has divine right in anything, except insofar as it is distributed or granted by the pope." Church," the "Chief Priest" with "general superintendence" so that "all those below him are subordinate and subject to him," but that does not mean that the pope is the source of all the authority of the bishops. "I" is preposterous to keep reiterating the authority of the pope, since that much is clear," writes Vargas, "but not in the way that the legate intends." 100 Vargas points out that, in reality, the power and jurisdiction given to bishops to govern their respective dioceses-the so-called potestas iurisdictionis-comes directly from God, not the pope, which means that the pope cannot "take them away or reduce them without reason." 101 Vargas cites the support of Augustine, Cyprian, Jerome, Chrysostom, Bernard, and Gregory, corroborated by the "interpretation and consensus of the Church."102 Furthermore, the same clause challenges the

95. "Praeterea, falsum aliquibus ualde uidetur, quod sicut Deus praesidet in caelesti hierarchia, ita Papa in ecclesiastica. Nam a Deo sic dependent omnia” (Gutiérrez, Trento: un concilio, 2:50).

96. "Adde etiam quod, cum potestas ipsius sit ministerialis [...] certis regulis, certis limitibus et repagulis debere contineri [...]; dedit enim illi Deus sicut et aliis Apostolis potestatem non ad destructionem sed ad edificationem, ut Apostolus docet 1 Cor. ep. [2 Cor 10, 8; 13,10]" (Gutiérrez, Trento: un concilio, 2:51). 97. "Ha pretendido poner cierta cláusula por la cual virtualmente quiere determinar la quistión de que el papa es sobre el concilio" (Gutiérrez, Trento: un concilio, 2:131; see also 2:170).

98. "el legado pretende que ningún obispo ni prelado tenga derecho de Dios en cosa alguna, sino por distribución y concesión del papa” (Gutiérrez, Trento: un concilio, 2:131).

99. "[el papa] es príncipe y vicario en toda la Iglesia y primer hierarcha, que tiene superintendencia general, al cual todos los inferiores están subordinados y subietos” (Gutiérrez, Trento: un concilio, 2:132). 100. "es fuera de propósito inculcar tantas veces la potestad del papa, que ella se está clara, pero no de la manera que el Legado la pretende" (Gutiérrez, Trento: un concilio, 2:150).

101. "el papa, ni se los puede quitar ni disminuir sin causa" (Gutiérrez, Trento: Un concilio, 2:132).

102. "según Augstino, Cypriano, Hierónimo, Chrisóstomo, Bernardo, Gregorio e interpretación e consenso de la iglesia" (Gutiérrez, Trento: un concilio, 2:132). For an analysis of the treatment of this 
rights of bishops when it comes to granting benefices in their dioceses, as well as the provision of benefices and dignities by secular rulers in the dioceses in their dominions, which "notably" affected Charles V. ${ }^{103}$ Vargas summarizes by saying that ultimately, the clause deals with questions related to the power of jurisdiction, not the sacrament of order, so that it was not pertinent to include it in that decree. ${ }^{104}$

The second version of the draft on the sacrament of order was presented to the whole body of prelates on 21 January. ${ }^{105}$ In this version, despite the large number of minor corrections, the substance of the clause reappears, which meant that the protests of the Archbishop of Sassari and the Bishop of Orense had not been heeded. The text of the draft was to be voted at the conciliar session of 25 January. At that session, only two decrees were finally passed: the one postponing the session until 19 March, and the new one granting safe conduct to the Protestants who were to attend. The anticipated voting for the decrees on the Mass, the sacrament of order, and Communion under both kinds was postponed at the behest of the envoys of the duke of Saxony, who requested that they wait for the Protestant theologians to examine these questions. ${ }^{106}$

The draft of the doctrine on the sacrament of order remained on the table in the weeks that followed until the council was suspended permanently on 28 April. ${ }^{107}$ Until then, both Vargas and Toledo continued to show concern at the possibility that the draft would eventually be voted through: "I am greatly afraid that the Legate will get away with his plan, in order to boast that he has given the Apostolic See more than all those [other legates] in the past [during the first phase of the council]." 108 In the instructions and memorials written

doctrine at the Council of Trent, see Giuseppe Alberigo, Lo sviluppo della dottrina sui poteri nella Chiesa universale. Momenti essenziali tra il XVI et il XIX secolo (Rome: Herder, 1964), 11-101.

103. "[perjudiciales] a toda la iglesia y derechos de obispos y provisiones de beneficios y dignidades y patronadgos de príncipes de las iglesias catedrales, y señaladamente de Su Majestad" (Gutiérrez, Trento: un concilio, 2:149; see also 2:329).

104. Gutiérrez, Trento: un concilio, 2:48 and 150.

105. CT, 7:483; Jedin, Storia, 3:504-05. The second version, slightly revised, was edited by Gutiérrez, Trento: un concilio, 2: 21-41, and can also be read in CT, 7: 487-88, with variants in footnotes.

106. Jedin, Storia, 3:530.

107. CT, 7:549-52.

108. "Tengo gran temor no salga el Legado con su intento, para gloriarse que ha dado más a la Sede Apostólica que todos cuantos han pasado" (Gutiérrez, Trento: un concilio, 2:149). 
at the end of January, the question of the clause takes on greater importance than the Protestant theologians arriving in Trent. ${ }^{109}$ On 28 January, Toledo, for example, sought urgent instructions from Charles $\mathrm{V}$ about how to deal with this issue. ${ }^{110}$ Vargas, who was sent to Innsbruck by Toledo on 1 February, explained the implications of the clause, in person, to Charles V and Granvelle. ${ }^{111}$ The emperor and Granvelle supported the action that Vargas and Toledo had taken at the council concerning the clause. At the same time, it should be pointed out that the meddling of the imperial side in the sub-committee debates about the draft was carried out without their knowing at the time what Charles V's own attitude was about the best way to proceed. ${ }^{112}$ This action initiated by Vargas emphasizes that, in ecclesiological terms, a red line existed in the context of negotiations based on accommodating the papal legates.

Vargas repeatedly reflected on the best way to negotiate with the legates. The major obstacle, which he mentions in his correspondence and reports and which most of those attending the council also pick up on, was the fact that the legates controlled the agenda of topics for discussion. In the first of the bulls issued for holding a council (20 March 1537), the text specified that, as the legates presided, they had full rights to propose and manage the topics of debate within the council. ${ }^{113}$ In the decree concerning the holding of the council passed at the beginning of its third stage (18 January 1562), it was repeated that topics deemed appropriate for the general council proposed by the presiding legates would be dealt with at the council. ${ }^{114}$ The precedent for the assignment of these rights to the legate was Pope Martin V's bull, Dum onus, which appointed

109. Gutiérrez, Trento: un concilio, 2:241.

110. Gutiérrez, Trento: un concilio, 2:166.

111. Gutiérrez, Trento: un concilio, 2:329.

112. For Charles V's and Granvelle's support of Vargas, see Gutiérrez, Trento: un concilio, 2:241; Nuntiaturberichte, 12:192.

113. “omnia proponendi, ordinandi et de ipsius concili consilio decernendi et statuendi” (CT, 4:394).

114. "and that in it, due order being observed, those matters be treated which will seem appropriate and suitable to the holy council, on the proposal of the legates and presidents" (Decrees, 2:723). For the negotiations made by the legate Morone to secure acceptance of this clause, see Umberto Mazzone, "Giovanni Morone legato al Concilio di Trento e la clausola proponentibus legatis," in Il cardinale Giovanni Morone e l'ultima fase del Concilio di Trento, ed. Massimo Firpo and Ottavia Niccoli (Bologna: il Mulino, 2010), 117-41. 
Giuliano Cesarini as papal legate for the Council of Basel (1 February 1431). ${ }^{115}$ The actions of the legates tended to follow the same pattern during the three periods of the council, and "bishops and rulers challenged this much-resented provision, but to no avail." ${ }^{16}$ As Vargas himself bitterly summarized it, "the council was in Rome, and the execution of it was in Trent." 117

Examining the functions assigned to the legates was an ongoing debate during all the stages of the council. Vargas examines the actions of the papal legates from the point of view of those functions that they should be given as presidents of the council, making a distinction between honorary presidency and one that was authoritative or coercive. Legates at a general council have honorary presidency, like the one held by the former "discretionary judges" chosen by the emperor. ${ }^{118}$ The legates at Trent, however, acted as if they had "authoritative and coercive" presidency, based on "the order" that was followed at the Fifth Lateran Council, as if that council had in fact been the "model of a universal council." 119 Vargas recalls that at session 17 of the Council of Basel, the legates of Pope Eugenius IV had been accepted on the condition that "they [were] to be without coercive jurisdiction (iurisdictione coactiva)." ${ }^{120}$ He refers to several passages in the Acts of the Apostles (1: 15; 8: 14; 15: 13ff), which would confirm that while Peter was a "prince and universal shepherd in the Church," he never presided over councils "authoritatively or coercively." ${ }^{21}$

In his Apuntamientos, Vargas describes the behaviour of the legates at the working sessions of the council, the so-called particular congregations, or "classes," three preliminary working groups, organized and overseen by each of

115. Stieber, 11n3. See Gerald Christianson, Cesarini: The Conciliar Cardinal: The Basel Years, 1431-1438

(S. Ottilien: EOS-Verlag, 1979), 10-11, 22.

116. O'Malley, 9.

117. "el concilio ha sido en Roma y en Trento la ejecución de él" (Gutiérrez, Trento: un concilio, 1:223).

118. "los que presidían [...] eran jueces puestos por los Emperadores, a los cuales llamaban jueces discretivos" (Gutiérrez, Trento: un concilio, 1:210-11).

119. "los Legados del Papa se han aplicado la presidencia no solamente honoraria [...], pero también la auctoritativa y coactiva, siguiendo en todo el orden del concilio Latheranense Segundo de León X [...] como si fuese él ejemplar y concilio universal" (Gutiérrez, Trento: un concilio, 1:215).

120. Decrees, 1:477. Granvelle, 6:487-88. See Christianson, Cesarini, 115, 117.

121. "sant Pedro era príncipe y pastor universal en la Iglesia, no se ve haber presidido autoritativa ni coactivamente [Acts 1:15; 8:14; 15:13ss]" (Gutiérrez, Trento: un concilio, 1:211). 
the legates that operated only during the first stage of the council. ${ }^{122}$ According to Vargas, when the legates "proposed" a subject for examination in these preliminary meetings, "they were subtly hinting at their own opinion, and often before the Fathers could give their placet, they had already said displacet." ${ }^{23}$ If they noticed that "some prelate was not voting the way they wanted," they would come back at them "before the others could vote, sometimes with soft words, sometimes with harsh ones" with a contradiction, and hinting "to the others which way they should vote." 124 If, after this, they did not achieve their purpose, states Vargas, they would negotiate with the prelates "using the ways and means at their disposal" so that "some of them would change their minds," or they would require more time "for piety's sake and to examine matters more closely." 125 The negotiations were managed in accordance with the instructions received from the pope, with whom they were in permanent contact through the couriers who were constantly coming and going (it took three days by horse from Rome to Trent, and the regular post took another two days). ${ }^{126}$ Vargas concludes that "anything substantial that has been achieved here has come from Rome, from the deliberations on the matter between the Pope and the cardinals, who were permanently deputized to deal with this business." 127

Vargas's portrait of the action of the legates during the first stage of the council is undoubtedly a simplification of a much more complicated state of affairs (he does not consider the tensions between the legates and the respective popes, for example), but has its roots in facts confirmed by sources of the period. Hubert Jedin indicates that the legates in the general congregations gave the

122. For these particular congregations, see Jedin, Storia, 2:69-70.

123. "ordenaron de hacer tres clases, que cada legado tuviese la suya"; "los legados, cuando proponían, daban a entender su parescer, y muchas veces primero que los Padres dijesen el placet, ya ellos habían dicho el displacet" (Gutiérrez, Trento: un concilio, 1:215, 217-18).

124. "no pocas veces ha acontecido en el medio del votar, cuando veían que algún prelado no votaba a su gusto, tomar la mano a responder antes que los otros votasen, y unas veces con palabras blandas y otras veces con rigurosas contradecir y dar a entender a los otros lo que habían de votar" (Gutiérrez, Trento: un concilio, 1:218).

125. "negociar-por los modos que ellos tenían-que algunos mudasen propósito. Esto hicieron mucho tiempo [...] haciéndolo a título de piedad y examinar mejor las materias" (Gutiérrez, Trento: un concilio, $1: 216)$.

126. O’Malley, 8.

127. "Todo lo sustancial que aquí se ha hecho, de Roma ha venido, de lo que el Papa con los cardenales que para esto continuamente tenía diputados determinaba" (Gutiérrez, Trento: un concilio, 1:223). 
floor to speakers and seldom took it away; nor did they generally use calls to order. He also draws attention to the fact that the authority to propose topics for discussion did not mean that the bishops could not present "motions from the floor." ${ }^{228}$ Nonetheless, as Vargas explains in his Apuntamientos, the negotiating of topics and votes began in the "three classes" mentioned previously, that is, before the general congregations, so that when the congregations started, "what was to be done, had almost always been determined."129 The legates were also the ones who chose the members who would make up these classes, sometimes without even consulting the prelates, "delegating to each class those prelates whose opinion coincided with their own." ${ }^{130}$ Likewise, the legates would privately meet the most influential prelates or even the personal agents of the secular rulers to try and close down complicated issues before they could be voted on. ${ }^{131}$ Finally, although the bishops had the opportunity to present legates with their proposals for issues to be discussed at the council, the proposals were filtered by the legates themselves, without anyone having the authority to prevent it. ${ }^{132}$ As Vargas points out, it was impossible to put topics on the agenda that the legates did not want to examine, "even if the whole synod wanted it." ${ }^{133}$

An episode that Vargas comments on in his correspondence reflects the lack of freedom repeatedly condemned by the prelates attending the council and the ambassadors of each of the secular rulers who had representation at Trent. During the discussion about the introductory formula for the decree to be passed at the second session of the council in January 1546, various bishops protested at the fact that the one containing the form of words that designated the council as the representative of the universal church (universalem ecclesiam repraesentans) had not been included. ${ }^{134}$ This phrase, "Catholic truth," for Vargas, was associated with the conciliar understanding of general councils,

128. Jedin, Storia, 2:545; cf. O’Malley, 9.

129. "estaba quasi siempre determinado lo que se había de hacer" (Gutiérrez, Trento: un concilio, 1:227).

130. "diputando a cada clase los perlados que les parescían al propósito suyo" (Gutiérrez, Trento: un concilio, 1:215-16); CT, 4:572ff; O’Malley, 86.

131. For an example, see Jedin, Storia, 2:49.

132. For an example, see Gutiérrez, Trento: un concilio, 1:515-17, 541-69, 579-88.

133. "en lo que no querían, era por demás, aunque todo el sínodo lo quisiese" (Gutiérrez, Trento: un concilio, 1:216).

134. Jedin, Storia, 2:32-33; Adriano Prosperi, Il Concilio di Trento: una introduzione storica (Turin: Einaudi, 2001), 40-41; O’Malley, 79. 
since it was the opening text of the Haec sancta decree approved at the Council of Constance. ${ }^{135}$ The debate on this question had tended to give the impression that inclusion of the clause would be accepted, and yet only nine prelates-a third of the total-carried on protesting at its absence. The legates promised that the clause would be included in future decrees, which ensured that the nine prelates ended up voting in favour of the draft presented by the legates. ${ }^{136}$ Accepting the clause jeopardized the legates' own authority within the council, but at the same time, they could not openly reject the clause in order to maintain the illusion that the council was truly free. Vargas points out that the legates, as was typical of them, avoided direct discussion of the subject "because of secret motives that they had in it," and did little but drag their feet and promise that they would add the words to the decrees in the future sessions; "they kept those Fathers who were clamoring for [the introduction of the clause] waiting from one session to the next", and in the end, "as a result of the later suspension [1552], the promise was not honoured." ${ }^{37}$

Vargas recalled this 1546 episode in a letter sent from Rome to the Archbishop of Granada, Pedro Guerrero, in January 1562, just as the third period of the council was getting underway. For Vargas, the action of the legates concerning the inclusion or not of the universal ecclesiam rapraesentans clause in the conciliar decrees was analogous to Pope Pius IV's handling of the papal confirmation of the decrees and canons passed at the council during the first two periods. With reference to proceedings in 1546, Vargas states: "they were using delaying tactics and making promises (like they are doing now, talking about the continuance)." 138 The debate about this question arose in the summer of 1560 in the context of negotiations between the pope and the secular rulers for a resumption of the council that had been suspended in 1552 . The underlying problem was the same as the one raised by the clause in 1546,

135. "Si esta cláusula es verdad católica (como lo es), no hay por qué encubrirla ni callarla” (Granvelle, 6:499).

136. Jedin, Storia, 2:37; O’Malley, 79.

137. "aquellas [palabras] de que usó el Concilio de Constancia y el de Basilea, universalem ecclesiam repraesentans [...] jamás quisieron venir en ello por los fines secretos que en esto tenían, [...] y así de sesión en sesión trujeron suspendidos a los padres que clamaban por ello, [...] y con la suspensión que se hizo después, no se efectuó lo prometido" (Granvelle, 6:497-98).

138. "iban entreteniendo y prometiendo (como se hace agora en lo del expresar la continuación)" (Granvelle, 6:498). 
which was that asserting the need for papal confirmation implicitly questioned the infallibility of the general council and, in short, the doctrine on the councils fixed in the Haec sancta decree. Both the French King, Francis II, and the Emperor Ferdinand requested that the German Protestants be able to attend the general council, which would require the convening of a new councilvarious sites were touted such as Casale, Innsbruck, Lyons, or Vercelli-or at least a council that would accept revisions of decrees already passed during the first two periods of the Council of Trent. ${ }^{139}$ The need for papal confirmation enabled these two possibilities to be explored, but both were rejected by Philip II and Vargas, who demanded that the council be explicitly presented as a continuance of the unconcluded, suspended council at Trent in April 1552.

The pope consulted various theologians and jurists in the Curia, as well as several cardinals, for their opinions as to the best way to proceed. ${ }^{140}$ Among those consulted on the question of papal confirmation were Cardinal Jaume Pou (Giacomo Puteo) and Francisco de Vargas himself. Pou, a prestigious canonist who had been a candidate for the papacy in 1559 , pointed out that "there were diverse opinions" about this topic, but the most creditable one was that decrees passed at a general council did not "become binding" until they had been confirmed by the pope. Albert Pighius and Juan de Torquemada were among the authorities mentioned by Puteo. ${ }^{141}$ Vargas was unable to acknowledge the need for confirmation, because this implied denying the jurisdiction of the general council. In his reply to the pope, he argued that councils that were lawfully convened by the pope had never needed his confirmation. ${ }^{142}$ This course of action, according to Vargas, would be contrary to papal legislation itself. Among the arguments advanced by Vargas was the text of Pope Martin V's bull Inter cunctas (22 February 1418) on the articles by John Wycliffe and

139. Jedin, Storia, 4.1: 35-94; Alain Tallon, La France et le Concile de Trente (1518-1563) (Rome: École Française de Rome, 1997), 272-88.

140. Jedin, Storia, 4.1:60-61; Gutiérrez, Trento, un problema, 4:167.

141. "habiendo estudiado el cardenal Púteo sobre el dicho punto [...] le dijo: que aunque era punto sobre que había diversas opiniones, que la más cierta era que no ligaban antes de la confirmación del Pontífice Sumo, y que de esta opinión era un dotor moderno que se llamaba Pigio, y otro más antiguo que se llama Joanes de Turrecremata, hombre de gran autoridad" (Gutiérrez, Trento, un problema, 4:227; the letter is written by the Count of Tendilla and is addressed to Philip II). The opinion of Jaume Pou about the practice of papal confirmation of conciliar decrees was correct.

142. Gutiérrez, Trento, un problema, 4:247. 
John Huss, which had been condemned at Constance. ${ }^{143}$ This bull included a list of questions to be asked of those suspected of following the heresies of Wycliffe and Huss, such as whether the suspect being interrogated "believed, upheld or defended the argument that the universal Church was represented at any general council and also at the council of Constance," or whether they believed that whatever was passed at the council of Constance "had to be approved and upheld by all Christians, and whatever was condemned, believed and defended." ${ }^{144}$ For Vargas, this passage from the bull demonstrated that the confirmation of the pope was not necessary to give dogmatic validity to the decrees passed at the general councils.

In the beginning, Pope Pius IV agreed with Vargas, as he acknowledges in a letter of 5 October 1560, addressed to Philip II, who was in Madrid following the deliberations on the convening of the council: "Vargas was of our opinion," wrote the pope, adding that "we neither confirm the Tridentine council, nor do we invalidate it." 145 When the bull convening the council (Ad Ecclesiae regimen) was published two months later on 29 November, the text presented was deliberately ambiguous: on the one hand, it indicated that each and every suspension ("sublata suspensione quacumque") was lifted, but at the same time, use of the verb indicere suggested the idea of a new council ("indicimus"). ${ }^{146}$ Both Francis II and Ferdinand, as well as Philip II, were dissatisfied with the text of the bull. ${ }^{147}$ Vargas wrote to Philip II from Rome on 5 December, saying, “The

143. Gutiérrez, Trento, un problema, 4:194; Granvelle, 6:472.

144. "5. Item, utrum credat, teneat et asserat quod quodlibet concilium generale et etiam Constantiense, universalem Ecclesiam repraesentet. 6. Item, utrum credat, quod illud quod sacrum concilium Constantiense, universalem Ecclesiam repraesentans, approbavit et approbat in favorem fidei et ad salutem animarum, quod hoc est ab universis Christifidelibus approbandum et tenendum, pro condemnato credendum et asserendum" (Bullarum, diplomatum et privilegiorum sanctorum, ed. Francesco Gaude et al., 25 vols. [Turin: Seb. Franco, H. Fori et Henrico Dalmazzo, 1857-85], 4:673. However, Vargas did not take into account that the bull Inter cunctas "also reaffirmed the status of belief in papal supremacy as an article of faith" (Izbicki, Protector of the Faith, 98; see also 173).

145. "Varga era de l'opinione nostra [...]. Noi non confirmavamo el concilio Tridentino, nè ancho lo infirmavamo" (Gutiérrez, Trento, un problema, 4:234).

146. "sacrum oecumenicum et generale concilium [...] indicimus, et ibi celebrandum, sublata suspensione quacumque, statuimus atque decernimus" (Bullarum, 7:91).

147. For the political context of this episode, see Henry Outram Evennett, The Cardinal of Lorraine and the Council of Trent: A Study on the Counter-Reformation (Cambridge: Cambridge University Press, 1930); Jedin, Storia, 4.1:64-68; Tallon; O’Malley, 164-67. 
opinion in Germany and France is that it is not going to be very satisfying," and also informing him that "the Emperor's ambassador and the one from France state very clearly that it is the way the words have been presented, that the pope should either explicitly say continue, or the council should be opened again." ${ }^{48}$ For Philip II in particular, the bull had been written "in accordance with the opinion of those who were looking for a new bull of Indiction to weaken and destroy the authority of the Council of Trent and its decrees." ${ }^{49}$

The death of Francis II on 5 December marked the beginning of the regency of Catherine de' Medici. The threat of a national council, which was ever present during the reign of Francis II, now increased due to the pressure on the regent of France coming from both clergy and the laity. ${ }^{150}$ Rome feared that the national council would consolidate Calvinism, which would mean "France's separation from the papacy." ${ }^{151}$ Catherine asked Ferdinand to ask for a revision of the papal bull, otherwise she would have no other option than to call a national council to restore peace and religious unity in France. The fact that the council convened at Trent did not begin on Easter Day of 1561, the date anticipated in the bull, hastened the talks that would lead to the calling of the national council mentioned, although that meeting would be officially presented as a preparatory meeting for Trent. ${ }^{152}$ In that context, the desire to keep all parties happy, which had guided the bull of Indiction, quickly evaporated. So, in one of the conversations reported by Vargas to Philip II in a letter of 23 May 1561, Pius IV had told him that confirmation was necessary for the decrees to be valid: "those decrees are worth nothing until I have confirmed them." 153

148. "En Germania y Francia se piensa que no ha de satisfacer mucho, e ya el embajador del Emperador y el de Francia lo hablan claro, y dicen que es envolvimiento de palabras lo que se ha hecho, que el papa o había de decir expresamente continuar, o que de nuevo abría el concilio" (Gutiérrez, Trento, un problema, 4:295).

149. "la dicha bula se puede juzgar ha sido ordenada y formada conforme a la opinión de los que habían pretendido nueva indictión con fin de enflaquescer y aniquilar la auctoridad del concilio de Trento y decretos de él" (Gutiérrez, Trento, un problema, 4:383).

150. Tallon, 286.

151. Jedin, Storia, 4.1:42.

152. Jedin, Storia, 4:89; Tallon, 293.

153. "no valen nada aquellos decretos hasta que yo los confirme" (Gutiérrez, Trento, un problema, 5:65). 
In his correspondence, Vargas examines the reasons that he thought explained this development in Pius IV's position on the confirmation of sessions already held. Apart from reasons to do with political strategy and diplomacy, Vargas thought that the change in the attitude of Pius IV was related to his fear that the council would be constituted and proceed completely independently of Rome, and that the prelates of the Roman Curia would have persuaded the pope that he needed to confirm decrees passed at the council, with the excuse that the French prelates "agree that the council is above the pope." ${ }^{154}$ With the aim of resuming the council as soon as possible, salvaging its ecumenical status, and thus denying the need for papal confirmation, Vargas unsuccessfully tried to clear up the association between a general council and the absence of confirmation by reminding Pius IV that the two periods of the Council of Trent held so far had been lawfully called by Pope Paul III and Julius III and had been managed by their legates. ${ }^{155}$

In mid-July 1561, a few days before the start of the national council in France-called for 20 July, although it finally started on 31 July $^{156}$ - Juan de Ayala, Vargas, and Cardinal Charles Borromeo had a conversation that was significant in this context. Discussions were taking place at roughly the same time concerning the final draft of a secret papal brief, in which Pius IV acknowledged that the council was a continuation of the council suspended in 1552 . The brief was a diplomatic success on the part of Vargas, who had suggested the idea to Philip II in March of the same year following the latter's enquiry about the best way to resolve the problem of the papal bull calling the council, issued on 29 November of the previous year. ${ }^{157}$ The conversation between Vargas, Ayala, and Borromeo reflects the final stage of negotiations; the brief is dated 17 July. The draft presented to Borromeo by Ayala and Vargas pointed out that the decrees of the council had been dictated by the Holy Spirit ("utpote ab ipso Spiritu

154. "le han persuadido algunos esto por sus fines [...] so color que los prelados de Francia están en que el concilio sea superior al papa" (Gutiérrez, Trento, un problema, 5:65).

155. Gutiérrez, Trento, un problema, 5:231-32.

156. Jedin, Storia, 4:86. In July, contact was initiated with Théodore de Bèze to negotiate participating in a dialogue with the Calvinists to achieve religious peace, known as the Colloquy of Poissy, Tallon, 306. For this Colloquy, see Donald Nugent, Ecumenism in the Age of Reformation: The Colloquy of Poissy (Cambridge, MA: Harvard University Press, 1974).

157. Gutiérrez, Trento, un problema, 4:386, 428. Jedin (Storia, 4:85) attributed the credit for the negotiation to Ayala, but could not consult the correspondence edited by Gutiérrez. 
Sancto dictatis"). Borromeo revised the text and presented them with a new version from which that clause had disappeared. When Ayala and Vargas asked about the removal of the clause, Borromeo replied that those words "would be very strong and there was no way that the pope would write them." 158 The inspiration of the Holy Spirit might imply the direct authority of Christ over the council, which was why the clause could not be included. In the end, as Ayala and Vargas explain in the same letter, Pius IV agreed to include the reference to the Holy Spirit. ${ }^{159}$ The initial reticence is indicative, nonetheless, of the degree of sensitivity in the Roman Curia at the possible reappearance of conciliarism in light of the conciliar policy of Catherine de' Medici.

Giuseppe Alberigo pointed out some time ago that it was necessary to make a distinction between the Council of Trent and Tridentinism, that is to say, the later interpretation and application of the council itself. ${ }^{160}$ The proceedings of the council reflect disagreements on the main topics of contemporary ecclesiology and great difficulties in reaching consensus. Yves Congar claimed, and with good reason, that the Council of Trent did not really have an ecclesiology of its own. ${ }^{161}$ Nevertheless, Catholic historiography after the Council of Trent has created a monolithic, papalist picture of the conciliar ecclesiology that would eventually be articulated at the First Vatican Council. John O'Malley recalls that "all the prelates at Trent of course believed in papal primacy" although "they very much disagreed among themselves on the practical prerogatives that primacy entailed and especially the precise relationship between the papacy and the episcopacy and, more specifically, on the relationship between the

158. "el cardenal decía que aquellas palabras utpote ab ipso Spiritu Sancto dictatis serían las más recias, y que el papa no las ponía por ninguna vía” (Gutiérrez, Trento, un problema, 5:143).

159. Gutiérrez, Trento, un problema, 5:148.

160. Giuseppe Alberigo, “Du Concile de Trente au tridentinisme," Irénikon 54 (1981/2): 192-210. More recently, see John O’Malley, “The Council of Trent: Myths, Misunderstandings and Misinformation," in Spirit, Style, Story: Essays Honouring John W. Padberg SJ, ed. Thomas M. Lucas (Chicago: Loyola Press, 2001), 205-26; and Simon Ditchfield, "Tridentine Catholicism," in The Ashgate Research Companion to the Counter-Reformation, ed. Alexandra Bamji, Geerth H. Janssen, and Mary Laven (Aldershot: Ashgate, 2013), 15-31; O'Malley, 11 and 291-92 for a selection of recent bibliography on the application and interpretation of the Tridentine decrees.

161. Giuseppe Alberigo, "L'ecclesiologia del Concilio di Trento," in La chiesa nella storia (Brescia: Paideia, 1988), 178-96, 187-91. 
papacy and the council itself." ${ }^{162}$ The study of the conciliar theory of Francisco de Vargas presented in this article draws attention to the need to recover this variety of ecclesiological positions at the Council of Trent.

Vargas saw the Council of Constance, with its particular agenda of reform issues, as a model for the implementation of church reform that the majority of Catholics at the time desired. Using the ecclesiology of the Haec sancta decree as his basis, Vargas argued that the general council received its authority directly from Christ, so that it had its own jurisdiction and was infallible in decisions pertaining to the faith and practices. The pope had primacy in the church but was subject to the decisions of the council, an approach inconsistent with the ecclesiology modelled at the First Vatican Council but feasible in contemporary ecclesiology. Given the conditions in which the Council of Trent was set up, with legates having the exclusive right of proposal, conciliar theory could not be implemented, although it did not mean that Vargas abandoned his ecclesiological principles.

Neither Charles V nor Philip II had the academic training necessary to discern the nuances of an ecclesiological tradition founded on juridical and theological texts of the late Middle Ages and the beginning of the sixteenth century. Nevertheless, their correspondence between 1545 and 1563 shows that they did not see any incompatibility between conciliar theory and their political objectives in relation to the Council of Trent. The defense of freedom and the jurisdiction of the general councils reinforced the capacity of Charles and Philip to intervene at Trent in an indirect way, insofar as it was they who could choose the bishops who would have the right to vote in the congregations and conciliar sessions. Conciliar theory was perceived at court not as an instrument liable to justify a "popular or plebeian" regime, as the legate Umberto da Gambara had warned Charles V in 1531, but as a doctrine that created ideal conditions for pursuing the political interests of the Habsburgs. ${ }^{163}$

The increasingly decisive role of the inquisitorial tribunals in persecuting dissidence, the aggressive regalian policy against ecclesiastical freedom that Philip II tried to implement, and the growing power of the Jesuit Order were some of the factors that progressively pushed conciliarism to a secondary 162. O’Malley, 19-20.

163. "Ma se il concilio determinasse la autorità sua esser sopra quella di Pontifice et di V. M.tà et di qualunque altro, adherendo al decreto del concilio Costantiense [... ] saria simile al stato populare, anzi plebeio" (CT, 4:liv). 
position in the Catholic world during the second half of the sixteenth century. Strictly speaking, however, these phenomena no longer belong to the Council of Trent, but to the history of Tridentinism. 